\title{
Co-Infection Prevalence of Herpes Simplex Virus Types 1 and 2 with Human Papillomavirus and Associated Risk Factors among Asymptomatic Women in Ghana
}

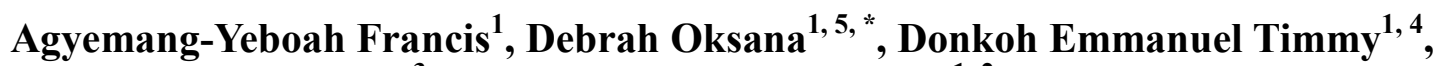 \\ Asmah Harry Richard ${ }^{3}$, Seini Mustapha Mohammed ${ }^{1,2}$ \\ ${ }^{1}$ Department of Molecular Medicine, Kwame Nkrumah University of Science and Technology, Kumasi, Ghana \\ ${ }^{2}$ Laboratory Department, Greater Accra Regional Hospital, Accra, Ghana \\ ${ }^{3}$ College of Health Sciences, University of Ghana, Legon, Accra, Ghana \\ ${ }^{4}$ University of Energy and Natural Resources, Sunyani, Ghana \\ ${ }^{5}$ Clinical Laboratory Unit, Institutional Care Division, Ghana Health Service, Accra, Ghana
}

\section{Email address:}

drfay1801@gmail.com (Agyemang-YeboahFrancis),oksanadeb@yahoo.com(O.Debrah),timmy.donkoh@uenr.edu.gh(E.T.Donkoh), rhasmah@chs.edu.gh(R.H. Asmah),maltitiseini@yahoo.com(M. M. Seini)

${ }^{*}$ Corresponding author

\section{To cite this article:}

Agyemang-Yeboah Francis, Debrah Oksana, Donkoh Emmanuel Timmy, Asmah Harry Richard, Seini Mustapha Mohammed. Co-Infection Prevalence of Herpes Simplex Virus Types 1 and 2 with Human Papillomavirus and Associated Risk Factors among Asymptomatic Women in Ghana. International Journal of Infectious Diseases and Therapy. Vol. 3, No. 3, 2018, pp. 45-51. doi: 10.11648/j.ijidt.20180303.11

Received: August 30, 2018; Accepted: September 21, 2018; Published: October 23, 2018

\begin{abstract}
Herpes simplex virus type 1 (HSV-1) and type 2 (HSV-2) are among the most common human viral infections worldwide and associated with increased risk for other sexually transmitted infections, such as HPV. Unfortunately, there is a dearth of population data on the joint epidemiology of HPV-HSV infections in Ghana. In order to determine the prevalence of HSV-1 and HSV-2 co-infection with HPV and associated risk factors, 317 asymptomatic women attending the Cervicare Centers in Ghana were invited to participate in cross-sectional study. Serum HSV-1 and HSV-2 IgG were determined by ELISA method. Genomic DNA from cervical swabs was extracted using QIAamp Mini kit. HPV-DNA detection was carried out by nested multiplex PCR as was described by Sotlar et al., (2004). The mean age of study participants was 40.7 years (SD \pm 11.2 ). Our result showed the prevalence of HSV-1 and HSV-2 infection among HPV positive women as $98.6 \%$ and $80.4 \%$ respectively. Among unscreened women participating in the study the co-infection of HSV-1/HPV and HSV-2/HPV was $42.9 \%$ and $35.0 \%$, respectively. Age of coitache was associated with sero-prevalence of HSV-1 ( $p=0.010)$, HPV infection $(\mathrm{p}=0.016)$, and with co-infection HPV and HSV-1 $(\mathrm{p}=0.025)$, HPV and HSV-2 $(\mathrm{p}=0.011)$ and weakly with single HSV-2 infection $(\mathrm{p}=0.054)$. In conclusion, the high prevalence of co-infection was due to the endemicity and inadequate intervention in the study population. A woman's age of sexual debut was a strong risk factor for co-infection of HPV and HSV-1 or HSV-2. The outcome of this novel observation stresses the urgent need to develop appropriate interventional strategies to manage and cancel patients presenting with asymptomatic genital herpes.
\end{abstract}

Keywords: Co-infection, Ghana, Herpes Simplex Virus, Human Papilloma Virus

\section{Introduction}

Herpes simplex virus type 1 (HSV-1) and type 2 (HSV-2) are among the most common human viral infections worldwide [1, 2]. Available estimates indicate that the worldwide prevalence of HSV-1 and HSV-2 infection is high and deserving of attention $[1,2]$. The highest prevalence of HSV infection of both types was reported in Africa (87\% in case of HSV-1 and $14.4 \%$ in case of HSV-2). In Ghana, the prevalence of HSV-1 and HSV-2 among women was found to be high (99.2\% and $78.4 \%$, respectively) [3]. HSV type 1 has been associated with orofacial infections and HSV type 2 
with genital infections. The tropism of the virus seems to have changed. Clinical reports indicate an increasing number of genital herpes infections caused by HSV -1 , although HSV -2 dominates as a causative agent $[4,5]$. The viruses infect humans of all ages and cause lasting and recurrent infections throughout life [4]. Reactivation results in symptomatic clinical disease or asymptomatic viral shedding $[6,7]$. The large majority of persons with genital herpes do not know they have the disease [8].

Genital herpes infection may be a co-factor in the acquisition and transmission of other sexually transmitted infections including Human Immunodeficiency virus (HIV) $[9,10]$, syphilis [11], hepatitis C virus [12], as well as Human Papillomavirus (HPV) [13].

HPV is another common sexually transmitted infection among women and is the main etiological factor for invasive and pre-invasive cervical cancer $[14,15]$. The adjusted global prevalence of HPV among women with normal cytology is $10.41 \%$, with considerable variation by region [16]. Again Africa has the highest age-adjusted prevalence of HPV of $22.12 \%$. The WHO estimates that $21.5 \%$ of women from West Africa have an infection at a given time [17].

Synergism between HPV, HSV -2 and induction of cervical cancer has been confirmed by laboratory experiments [18]. Ulcerative herpetic lesions may serve as a co-factor for HPV by facilitating the access of HPV to basal cells of the epithelium or HSV infection may increase HPV replication or integration of HPV DNA sequences in infected host cells $[18,19]$. The fact that transmission through viral shedding continues, in frequent asymptomatic cases with HSV, has sustained the worsening of the pandemic [20]. Women sero-positive for HSV-2 and infected with high -risk HPV have two-fold increased risk of cervical cancer [21]. However, data on prevalence of co-infection of HSV-1, HSV-2 with HPV infections are limited in Ghana. This study aimed to provide data on HSV and HPV and associated risk factors among asymptomatic women in Ghana.

\section{Materials and Methods}

\subsection{Study Design and Settings}

This was a cross-sectional study, in which 317 women who reported to the Cervical Centers (Kumasi South Regional Hospital, Kumasi, Ashanti Region, and Ridge Regional Hospital, Greater Accra Region, Accra) with various degrees of gynecological or obstetric complaints were randomly recruited into the study over a six-month period (October, 2014 - March, 2015). Participants into the study were $\geq 20$ years and non-pregnant.

All participants gave informed consent and a standardized questionnaire was administered through one-on-one interview for data collection on socio-demographic, reproductive history, sexual behavior, knowledge of HPV and HSV infection.

\subsection{Ethical Approval}

The study was approved by the Committee on Human
Research Publication and Ethics (CHRPE), Kwame Nkrumah University of Science and Technology, School of Medical Sciences (KNUST-SMS) and Komfo Anokye Teaching Hospital (KATH) (CHRPE/AP/115/14), Kumasi, Ghana and Ghana Health Service Ethical Review Committee, Research and Development Division (GHS-ERC:07/03/14). Voluntary written informed consent was also sought from the participants.

\subsection{Sample Collection}

Venous blood samples were collected in the plain vacutainer tube $(5 \mathrm{ml})$ and allowed to clot before centrifugation. Serum was aliquoted into eppendorf tubes for storage at $-200 \mathrm{C}$ till analyzed.

Cytological specimens were obtained from all subjects and suspended in DNAgard (Biomatrica Co., San Diego, USA) for DNA preservation at room temperature (for up to 3-6 months) until DNA extraction.

\subsection{DNA Extraction}

Genomic DNA from cervical swabs was extracted using commercial spin-column based QIAamp Mini kit (QIAGEN, Hilden, Germany).

\subsection{HSV-1 and HSV-2 IgG Determination}

Serum HSV-1 IgG and HSV-2 IgG were determined by ELISA method using commercial test kits from Calbiotech Inc., CA, USA. The manufacturer's instructions were followed for the analyses.

\subsection{DNA Genotyping}

HPV-DNA detection and identification of the 18 genotypes was carried out by nested multiplex PCR as was described by Sotlar et al. (2004). A single consensus forward primer (GP-E6-3F) and two consensus back primers (GP-E7$5 \mathrm{~B}$ and GP-E7-6B) were used for the general primer PCR. In the second round PCR, first round PCR product, forward and reverse primers for genotyping were used. Primers for the identification of high-risk genotypes $16,18,31,33,35,39$, $45,51,52,56,58,59$; probably-high risk genotypes 66 and 68 , and low-risk genotypes $6 / 11,42,43$, and 44 were used in four cocktails, each containing four to five different primer pairs. The amplified products were detected by $2 \%$ agarose gel electrophoresis. Hundred base pair DNA molecular weight marker was run alongside the PCR products.

\subsection{Statistical Analysis}

Data obtained were verified for consistency, coded and analyzed by using the Statistical Package for the Social Scientists (SPSS) version 22. Qualitative variables were described by simple counts and percentages. Quantitative variables were represented as mean $\pm \mathrm{SD}$. All HPV types were classified as high risk, probably high risk and low risk. The co-infection of HPV with HSV was calculated as the proportion of cases in the study population. The relation of 
HPV and HSV positivity with demographic, gynecological and behavioral differences was examined by the Chi-squared test and the Fisher's test. Statistical significance was accepted for P-value $<0.05$.

\section{Results}

\subsection{Socio-demographic and Obstetric Characteristics of Study Participants}

The mean age of women participating in the study was $40.0 \pm 10.8$ years (range, 21-76 years). The majority of them
$(34.1 \%)$ were in the $25-34$ years age category and married (56.8\%) (Table 1). A large proportion of the study population were literates, $37.5 \%$ completed Junior high school, $11.0 \%$ Secondary high school and $24.0 \%$ - tertiary education, while $9.8 \%$ and $12.0 \%$ never attending a school or completed only primary education, respectively. The main occupation of women was trading $(40.7 \%)$ followed by other means of selfemployment (17.4\%). Most of the respondents (39.1\%) had their first pregnancy before 21 years, where $31.9 \%$ had more than 5 pregnancies (Table 2).

Table 1. Study population demographics \& HSV -1, HSV-2 and HPV co-infections prevalence among women.

\begin{tabular}{|c|c|c|c|c|c|c|}
\hline Characteristics & ${ }^{1} \mathrm{~N}(\%)$ & $\begin{array}{l}{ }^{2} \mathrm{HSV}-1 \\
\text { N (\%) }\end{array}$ & $\begin{array}{l}{ }^{2} \mathrm{HSV}-2 \\
\mathrm{~N}(\%)\end{array}$ & $\begin{array}{l}{ }^{2} \mathrm{HPV} \\
\mathbf{N}(\%)\end{array}$ & $\begin{array}{l}{ }^{2} \mathrm{HSV}-1 / \mathrm{HPV} \\
\mathrm{N}(\%)\end{array}$ & $\begin{array}{l}{ }^{2} \mathrm{HSV}-2 / \mathrm{HPV} \\
\mathrm{N}(\%)\end{array}$ \\
\hline \multicolumn{7}{|l|}{ Age group, years } \\
\hline$\leq 25$ & $8(2.5)$ & $8(100.0)$ & $6(75.0)$ & $6(75.0)$ & $6(75.0)$ & $5(62.5)$ \\
\hline $25-34$ & $108(34.1)$ & $106(98.1)$ & $88(81.5)$ & $50(46.3)$ & $49(45.4)$ & $42(38.9)$ \\
\hline $35-44$ & $107(33.8)$ & $107(100.0)$ & $87(81.3)$ & $45(42.1)$ & $45(42.1)$ & $37(34.6)$ \\
\hline $45-54$ & $58(18.3)$ & $58(100.0)$ & $46(79.3)$ & $25(43.1)$ & $24(41.4)$ & $20(34.5)$ \\
\hline $55-64$ & $29(9.1)$ & $29(100)$ & $25(86.2)$ & $10(34.5)$ & $9(31.0)$ & $8(27.6)$ \\
\hline$\chi^{2}(\mathrm{df})$ & & $3.895(5)$ & $1.248(5)$ & $5.261(5)$ & $5.972(5)$ & $5.311(5)$ \\
\hline $\mathrm{p}$-value & & 0.565 & 0.940 & 0.385 & 0.309 & 0.379 \\
\hline \multicolumn{7}{|l|}{ Education } \\
\hline Never attended & $31(9.8)$ & $31(100.0)$ & $26(83.9)$ & $8(25.8)$ & $8(25.8)$ & $7(22.6)$ \\
\hline Primary & $38(12.0)$ & $38(100.0)$ & $32(84.2)$ & $12(31.6)$ & $12(31.6)$ & $11(28.9)$ \\
\hline Middle / JHS & $119(37.5)$ & $119(99.3)$ & $101(84.9)$ & $43(31.6)$ & $43(36.1)$ & $40(33.6)$ \\
\hline SHS & $35(11.0)$ & $35(100.0)$ & $27(77.1)$ & $24(68.6)$ & $24(68.6)$ & $17(48.6)$ \\
\hline Technical & $18((5.7)$ & $18(100.0)$ & $13(72.2)$ & $9(50.0)$ & $9(50.0)$ & 7 (38.9) \\
\hline$\chi^{2}(\mathrm{df})$ & & $6.382(5)$ & $3.914(5)$ & $22.308(5)$ & $19918(5)$ & $6.772(5)$ \\
\hline p-value & & 0.271 & 0.562 & 0.000 & 0.001 & 0.238 \\
\hline \multicolumn{7}{|l|}{ Marital status } \\
\hline Never married & $55(17.4)$ & $53(96.4)$ & $44(80.0)$ & $29(52.7)$ & $27(49.1)$ & $23(41.8)$ \\
\hline Divorced/separated & $26(8.2)$ & $26(100.0)$ & $22(84.6)$ & $12(46.2)$ & $12(46.2)$ & $10(38.5)$ \\
\hline Married & $180(56.8)$ & $180(100.0)$ & 147 (81.7) & $80(44.4)$ & $79(43.9)$ & $69(38.3)$ \\
\hline Cohabiting & $25(7.9)$ & $25(100.0)$ & $18(76.0)$ & $9(36.0)$ & $9(36.0)$ & $6(24.0)$ \\
\hline Widowed & $31(9.8)$ & $31(100.0)$ & $25(80.6)$ & $8(25.8)$ & $8(25.8)$ & $5(16.1)$ \\
\hline$\chi^{2}(\mathrm{df})$ & & $7.067(4)$ & $0.718(4)$ & $6.565(4)$ & $5.225(4)$ & $8.195(4)$ \\
\hline p-value & & 0.132 & 0.949 & 0.161 & 0.264 & 0.085 \\
\hline \multicolumn{7}{|l|}{ Occupation } \\
\hline Government employee & 44 (13.9) & $43(97.7)$ & $36(81.8)$ & $25(56.8)$ & $24(54.5)$ & $31(47.7)$ \\
\hline Private sector employee & $28(8.8)$ & $28(100.0)$ & $23(82.1)$ & $14(50.0)$ & $13(46.4)$ & $11(39.3)$ \\
\hline Self -employed & $55(17.4)$ & $55(100.0)$ & $39(70.9)$ & $29(52.7)$ & $29(52.7)$ & $22(40.0)$ \\
\hline Trader & $129(40.7)$ & $129(100.0)$ & $111(86.0)$ & $48(37.2)$ & $47(36.4)$ & $42(32.6)$ \\
\hline House wife & $5(1.6)$ & $5(100.0)$ & $3(60.0)$ & $2(40.0)$ & $2(40.0)$ & $3(60.0)$ \\
\hline Unemployed & $28(8.8)$ & $28(100.0)$ & $21(75.0)$ & $9(32.0)$ & $9(32.1)$ & $5(17.9)$ \\
\hline Retired & $9(2.8)$ & $9(100.0)$ & 8 (88.9) & $2(22.2)$ & $2(22.2)$ & $2(22.2)$ \\
\hline$\chi^{2}(\mathrm{df})$ & & $7.309(8)$ & $9.242(8)$ & $11.936(8)$ & $11.057(8)$ & $10.136(8)$ \\
\hline p-value & & 0.504 & 0.322 & 0.154 & 0.199 & 0.256 \\
\hline
\end{tabular}

${ }^{1}$ Column percentage calculated with reference to total number of participants $(\mathrm{N}=317)$

${ }^{2}$ Row percentage calculated with reference to total number of cases in a row.

Table 2. Study population obstetric characteristics \& HSV -1, HSV-2 and HPV co-infections prevalence among women

\begin{tabular}{|c|c|c|c|c|c|c|}
\hline Characteristics & ${ }^{1} \mathbf{N}(\%)$ & $\begin{array}{l}{ }^{2} \text { HSV-1 } \\
\text { N (\%) }\end{array}$ & $\begin{array}{l}{ }^{2} \text { HSV-2 } \\
\text { N (\%) }\end{array}$ & $\begin{array}{l}{ }^{2} \mathrm{HPV} \\
\mathbf{N}(\%) \\
\end{array}$ & $\begin{array}{l}{ }^{2} \mathrm{HSV}-1 / \mathrm{HPV} \\
\mathrm{N}(\%) \\
\end{array}$ & $\begin{array}{l}{ }^{2} \mathrm{HSV}-2 / \mathrm{HPV} \\
\mathrm{N}(\%) \\
\end{array}$ \\
\hline \multicolumn{7}{|c|}{ Age at first pregnancy (years) } \\
\hline$\leq 17$ & $27(8.5)$ & $27(100.0)$ & $26(96.3)$ & $4(14.8)$ & $4(14.8)$ & $5(18.5)$ \\
\hline $18-21$ & $97(30.6)$ & $97(100.0)$ & $80(82.5)$ & $45(46.4)$ & $45(46.4)$ & $38(39.2)$ \\
\hline $22-25$ & $76(24.0)$ & $76(100.0)$ & $66(86.8)$ & $31(40.8)$ & $30(39.5)$ & $28(36.8)$ \\
\hline$>25$ & $59(18.6)$ & $59(100.0)$ & $44(74.6)$ & $27(45.8)$ & $27(45.8)$ & $21(35.6)$ \\
\hline
\end{tabular}




\begin{tabular}{|c|c|c|c|c|c|c|}
\hline Characteristics & ${ }^{1} \mathbf{N}(\%)$ & $\begin{array}{l}{ }^{2} \mathrm{HSV}-1 \\
\text { N (\%) }\end{array}$ & $\begin{array}{l}{ }^{2} \mathrm{HSV}-2 \\
\mathrm{~N}(\%) \\
\end{array}$ & $\begin{array}{l}{ }^{2} \text { HPV } \\
\text { N (\%) } \\
\end{array}$ & $\begin{array}{l}{ }^{2} \mathrm{HSV}-1 / \mathrm{HPV} \\
\mathrm{N}(\%) \\
\end{array}$ & $\begin{array}{l}{ }^{2} \mathrm{HSV}-2 / \mathrm{HPV} \\
\mathrm{N}(\%) \\
\end{array}$ \\
\hline Never pregnant & $37(11.7)$ & $35(94.6)$ & $26(70.3)$ & $21(56.8)$ & $20(54.1)$ & $15(40.5)$ \\
\hline Do not remember & $21(6.6)$ & $21(100.0)$ & $15(71.4)$ & $10(47.6)$ & $9(42.9)$ & $6(28.6)$ \\
\hline$\chi^{2}(\mathrm{df})$ & & $15.231(5)$ & $11.560(5)$ & $12.508(5)$ & $11627(5)$ & $4871(5)$ \\
\hline p-value & & 0.009 & 0.041 & 0.028 & 0.040 & 0.432 \\
\hline \multicolumn{7}{|l|}{ Gravidae } \\
\hline 0 & 37 (11.7) & $35(94.6)$ & $26(70.3)$ & $21(56.8)$ & $20(54.1)$ & $15(40.5)$ \\
\hline $3-4$ & $108(34.1)$ & $108(100.0)$ & $92(85.2)$ & $48(44.4)$ & $45(42.6)$ & $41(38.0)$ \\
\hline$\geq 5$ & $101(31.9)$ & $101(100.0)$ & $81(80.2)$ & $35(34.7)$ & $36(35.6)$ & $31(30.7)$ \\
\hline$\chi^{2}(\mathrm{df})$ & & $8.689(3)$ & $4.072(3)$ & $6.456(3)$ & $4.421(3)$ & $1.749(3)$ \\
\hline p-value & & 0.034 & 0.254 & 0.091 & 0.219 & 0.626 \\
\hline
\end{tabular}

${ }^{1}$ Column percentage calculated with reference to total number of participants $(\mathrm{N}=317)$

${ }^{2}$ Row percentage calculated with reference to total number of cases in a row.

\subsection{HSV and HPV Co-infection Prevalence among Studied Participants}

In general, among women participating in the study the coinfection of HSV-1/HPV and HSV-2/HPV was $42.9 \%$ and $35.0 \%$, respectively.

The sero-prevalence of HSV-1 and HSV-2 infection among HPV- infected women was 98.6\% (136/138) and $80.4 \%$ (111/138) respectively. (Table 3$)$. There was no relation between the number of detected HPV positive cases and HSV-1 or 2 status. The mean age of women with coinfection of HPV and HSV-1 was 39.9 years $(\mathrm{SD} \pm 10.8)$ is similar among HPV- negative women with HSV-1 serostatus, 40.0 years $(\mathrm{SD} \pm 10.9)$. The mean age of women with co-infection of HPV and HSV-2 was 39.9 years $(\mathrm{SD} \pm 10.8)$, versus 40.0 years $(\mathrm{SD} \pm 10.8)$ among $\mathrm{HPV}$ - negative women with HSV-2 sero-status.

Majority of cases the cases of co-infection was among women with multiple HPV status (Table 3). Association has been seen in the co-infection of HSV-2 and HPV irrespective of whether the latter has a single or multiple infection $(\mathrm{p}=0.013)$. The higher prevalence of HSV-1 and HSV-2 infections was among HR HPV $(97.4 \%$ and $73.1 \%$, respectively).

Co-infection with any HPV DNA genotype and herpes infection type 1 and type 2 was not associated with sociodemographical characteristics such as age, marital status and employment status (Table 1).

Table 3. Co-infection of Herpes simplex virus and Human Papilloma virus among asymptomatic women in Ghana.

\begin{tabular}{|c|c|c|c|c|}
\hline HPV status & HPV Infection type & HPV Frequency ${ }^{1} \mathrm{~N}(\%)$ & HSV $-1^{+2} \mathrm{~N}(\%)$ & HSV $-2^{+2} \mathrm{~N}(\%)$ \\
\hline $\mathrm{HPV}^{-}$ & & $179(56.55)$ & $179(100)$ & $146(81.6)$ \\
\hline $\mathrm{HPV}^{+}$ & & $138(43.5)$ & $136(98.6)$ & $111(80.4)$ \\
\hline$\chi^{2} ; p$-value & & & $2.611 ; 0.106$ & $0.065 ; 0.799$ \\
\hline \multirow{5}{*}{$\chi^{2} ; p$-value } & Single & $60(18.9)$ & $60(100.0)$ & $54(90.0)$ \\
\hline & Multiple & $78(17.8)$ & $76(97.4)$ & $57(73.1)$ \\
\hline & & & $1.156 ; 0.212$ & $6.172 ; 0.013$ \\
\hline & HR- HPV & 111 & $109(98.2)$ & $88(79.3)$ \\
\hline & LR-HPV & 54 & $53(98.1)$ & $40(74.2)$ \\
\hline
\end{tabular}

${ }^{1}$ Column percentage was calculated to show within- group HPV prevalence infection

${ }^{2}$ Row percentage was calculated with reference to total number of cases in a row

HR-HPV- High risk HPV, PHR- Probably-high risk HPV, LR-HPV- Low-risk HPV

HR HPV genotypes: 16, 18, 31, 33, 35, 39, 45, 51, 52, 56, 58, 59; PHR-HPV genotypes: 66, 68; LR-HPV genotypes: 6/11, 42, 43, 44

\subsection{Risk Factors of HSV-HPV Co-infection}

Educational background of subjects was strongly associated with HPV infection and co-infection with HSV-1 ( $p=0.000$ and $p=0.001$, respectively). The higher prevalence of co-infection was among single women and divorced for HS- 1, whereas in the case of single HSV-2 infections prevalence is higher among divorced or cohabiting women.

History of young age at first pregnancy (before 21 years), was associated with significant prevalence for HSV-1 $(p=0.009)$, HSV-2 $(p=0.041)$, HPV $(p=0.028)$ and HPV coinfection with herpes virus type $1(\mathrm{p}=0.040)$, but not in the case of co-infection of HPV and HSV-2 ( $p=0.432)$. A woman's lifetime number of pregnancies was not significantly associated with co-infection.

Tables 4 shows the prevalence of co-infection HPV DNA of any genotypes and herpes infections type 1 and type 2 with behavioral characteristics of women participating in the study. There was no significant relationship between tobacco smoking and alcohol intake, as well as in condom usage. As expected, the age of coitache was a significant predictor for co-infection of both HSV-1 and HSV-2 with HPV DNA ( $p=0.025$ and $p=0.011$ respectively), as well as for individual infections. No association was observed for lifetime number of sex partners. However, there was an increase in the prevalence of HSV-1, HSV-2 and co-infection of HPV DNA and HSV-2 among the women who had more than two sexual partners during their lifetime. 
Table 4. Study population behavioral characteristics \& HSV -1, HSV-2 and HPV co-infections prevalence among women.

\begin{tabular}{|c|c|c|c|c|c|c|}
\hline Characteristics & ${ }^{1} \mathbf{N}(\%)$ & $\begin{array}{l}{ }^{2} \mathrm{HSV}-1 \\
\text { N (\%) }\end{array}$ & $\begin{array}{l}{ }^{2} \mathrm{HSV}-2 \\
\mathrm{~N}(\%) \\
\end{array}$ & $\begin{array}{l}{ }^{2} \mathrm{HPV} \\
\mathrm{N}(\%) \\
\end{array}$ & $\begin{array}{l}{ }^{2} \mathrm{HSV}-1 / \mathrm{HPV} \\
\mathrm{N}(\%)\end{array}$ & $\begin{array}{l}{ }^{2} \mathrm{HSV}-2 / \mathrm{HPV} \\
\text { N (\%) }\end{array}$ \\
\hline \multicolumn{7}{|c|}{ Age of coitarche (years) } \\
\hline$\leq 15$ & $22(6.9)$ & $22(100.0)$ & $19(86.4)$ & $3(13.6)$ & $3(13.6)$ & $3(13.6)$ \\
\hline $16-20$ & $171(53.9)$ & $171(100.0)$ & $141(82.5)$ & $71(41.5)$ & $70(40.9)$ & $55(32.2)$ \\
\hline $21-25$ & $42(13.2)$ & $40(95.2)$ & $31(73.8)$ & $20(47.6)$ & $19(45.2)$ & $17(40.5)$ \\
\hline$\geq 26$ & $20(6.3)$ & $20(100.0)$ & $12(60.0)$ & $10(50.0)$ & $10(50.0)$ & $6(30.0)$ \\
\hline Do not remember & $62(19.6)$ & $62(100.0)$ & $54(87.1)$ & $35(54.8)$ & $33(53.2)$ & $32(51.6)$ \\
\hline$\chi^{2}(\mathrm{df})$ & & $13.076(4)$ & $9.312(4)$ & $12.130(4)$ & $11.172(4)$ & $13.145(4)$ \\
\hline $\mathrm{p}$-value & & 0.010 & 0.054 & 0.016 & 0.025 & 0.011 \\
\hline \multicolumn{7}{|c|}{ Number of life time sex partners } \\
\hline 1 & $112(35.3)$ & $111(99.1)$ & $84(75.0)$ & 48 (42.9) & $46(41.1)$ & $36(32.1)$ \\
\hline 2 & $81(25.6)$ & $80(98.8)$ & $66(81.5)$ & $37(45.7)$ & $37(45.7)$ & $28(36.8)$ \\
\hline $3-9$ & $117(36.9)$ & $117(100.0)$ & $101(86.3)$ & $50(42.7)$ & $49(41.9)$ & $46(39.3)$ \\
\hline $10+$ & $7(2.2)$ & $7(100.0)$ & $6(85.7)$ & $3(42.9)$ & $3(42.9)$ & $3(42.9)$ \\
\hline$\chi^{2}(\mathrm{df})$ & & $1.381(3)$ & $4.902(3)$ & $0.204(3)$ & $0.446(4)$ & $1.486(4)$ \\
\hline $\mathrm{p}$-value & & 0.710 & 0.179 & 0.977 & 0.931 & 0.686 \\
\hline \multicolumn{7}{|l|}{ Tobacco use } \\
\hline Yes & $4(1.3)$ & $4(100.0)$ & $3(75.0)$ & $2(50.0)$ & $2(50.0)$ & $1(25.0)$ \\
\hline No & $313(98.7)$ & $311(99.4)$ & $254(81.2)$ & $136(43.5)$ & $133(42.5)$ & $112(35.8)$ \\
\hline$\chi^{2}(\mathrm{df})$ & & $0.026(1)$ & $0.097(1)$ & $0.069(1)$ & $0.091(1)$ & $0.200(1)$ \\
\hline $\mathrm{p}$-value & & 0.873 & 0.755 & 0.793 & 0.763 & 0.655 \\
\hline \multicolumn{7}{|c|}{ Alcohol consumption } \\
\hline Yes & $135(42.6)$ & $134(99.3)$ & $108(80.0)$ & $65(48.1)$ & $64(47.4)$ & $50(37.0)$ \\
\hline No & $182(57.4)$ & $181(99.5)$ & $149(81.9)$ & $73(40.1)$ & $71(39.0)$ & $63(34.6)$ \\
\hline$\chi^{2}(\mathrm{df})$ & & $0.045(1)$ & $0.176(1)$ & $2.037(1)$ & $2.235(1)$ & $0.198(1)$ \\
\hline p-value & & 0.832 & 0.675 & 0.153 & 0.135 & 0.656 \\
\hline \multicolumn{7}{|l|}{ Condom use } \\
\hline Yes & $108(34.1)$ & $107(99.1)$ & $82(75.9)$ & $52(48.1)$ & $52(48.1)$ & $37(34.3)$ \\
\hline No & $209(65.9)$ & $208(99.5)$ & $175(83.7)$ & $86(41.1)$ & $83(39.7)$ & $76(36.4)$ \\
\hline$\chi^{2}(\mathrm{df})$ & & $0.227(1)$ & $2.828(1)$ & $1.419(1)$ & $2.072(1)$ & 0.137 (1) \\
\hline $\mathrm{p}$-value & & 0.633 & 0.093 & 0.234 & 0.150 & 0.711 \\
\hline
\end{tabular}

${ }^{1}$ Column percentage calculated with reference to total number of participants $(\mathrm{N}=317)$

${ }^{2}$ Row percentage calculated with reference to total number of cases in a row.

\section{Discussion}

Both HSV-1 and HSV-2 are a major global health concern, with a number of negative health outcomes $[1,2]$. Both types of HSV could be responsible for genital herpes. [1, 5]. HSV plays a role as a co-factor in the acquisition of HPV infection [1]. This is the first study, to our knowledge, to report on the co-infection of HSV type 1 and type 2 and HPV among women in Ghana. Among unscreened women participating in the study rate of co-infection of $\mathrm{HSV}-1 / \mathrm{HPV}$ and HSV$2 / \mathrm{HPV}$ was $42.9 \%$ and $35.0 \%$, respectively. The seroprevalence of HSV-1 and HSV-2 infection among HPVinfected women of any genotype was $98.6 \%$ (136/138) and $80.4 \%(111 / 138)$ respectively (Table 3$)$. The highest coinfections of herpes virus was seen with high-risk group HPV virus (HSV-1/HR HPV and HSV-2/HR HPV were 98.2\% and $79.3 \%$ respectively). The high prevalence of co-infection is not surprising; most women are unaware that they may be infected with HPV and HSV. Approximately, 60-95\% of adult women are infected with herpes infection which is usually present in the infected individual as latent infections. Infection and reactivation are mostly asymptomatic and the course of an infection depends of the host immune system and persistence of infection [8, 22]. Our study observed a high prevalence of HSV-1 and HSV-2 among HPV-negative women $(100 \%$ prevalence of HSV-1 and $81.6 \%$ prevalence of HSV-2). The knowledge of the double burden of these two viruses' is very necessary, because HSV and HPV are transmitted sexually and infect the same cell type and they have a potential to interact with each other. It has been observed that HSV infection may increase susceptibility to HPV causing alterations of epithelial cells and due to that facilitating the entry of HPV virion [23]. Synergism between HPV and HSV can lead to induction of cervical cancer, which is leading cause of mortality in low income countries, including Ghana [24, 25]. It was reported that among women infected with high-risk types of HPV, serological evidence of past herpes infection type 2 was associated with approximately two-fold increased risk of development of precancerous cervical lesions and invasive cervical cancer [21].

The current study also examined the correlation of coinfection with genital HPV and HSV-1 and HSV-2 and their socio-demographical, obstetric and behavioral characteristics to find the women at risk. Age, marital status, and occupation were not significant independent predictors for co-infection of both viruses (Table 1). Level of education was reported as a risk factors for sexually transmitted disease in a number of studies [26, 27]. In general low educational status is thought to indicate poor knowledge and compliance for safer sexual behavior; including number of sex partners and use of 
protective condoms [26, 28]. However, in the present study, women with SHS and tertiary level was inversely associated with HPV and HPV/HSV-1 co-infection than those reporting relatively fewer years of formal education (Table 4). Our result suggest that higher education may not necessarily be indicative of knowledge of HPV and HSV transmission or safer sexual behavior. For instance, semi-literate women reported safer condom-use relative to highly educated women: in general, condom use was quite low in current study (34.1\% of women) (Table 4$)$.

There was no significant trends in co-infection of HSV-1 and HPV as well as HSV-2 and HPV prevalence for majority of behavioral characteristics, such as number of sexual partners, tobacco smoking, alcohol intake and use of condom (Table 4). However, prevalence of HPV and HSV coinfection decreased as the age of first sexual exposure increased. This association was found to be statistically significant in both types of herpes viruses with HPV ( $p=0.026$ for $\mathrm{HSV}-1 / \mathrm{HPV}$ co-infection and $\mathrm{p}=0.007$ for HSV-2/HPV co-infection). Interestingly, that the age of coitache was also significantly associated with HSV-1 $(p=0.010)$, HSV $-2(p=0.054)$ and HPV $(p=0.016)$ infections alone. Early exposure to sexual intercourse has therefore been linked to increased risk of sexually transmitted infections during adolescence [29]. The increased STI is partially due to a biologic predisposition of the immature cervix to infection if exposed [30]. The study also indicated that there was a higher prevalence of co-infection among patients with more than one sex partner (Table 4), even though it was not statistically significant. However, women with only one lifetime partner have a co-infection prevalence $\mathrm{HSV}-1 / \mathrm{HPV}$ and HSV-2/HPV of $41.1 \%$ and $32.1 \%$ respectively. The increasing number of sexual partners may be related to transmission in this population of the sexually transmitted agents. In general population women's high coinfection of HSV-1 and HSV-2 with HPV cannot be explained only by their sexual risk behavior. This is more likely that high co-infection rate results from the behavior and sexual network of women's primary partners.

\section{Conclusion}

The present study estimated the high co-infection of herpes virus type 1 and type 2 with HPV in a population of healthseeking women in Ghana, which can be due to the high transmission of the viruses, lack of awareness of viral infections among the population and inadequate intervention in the population. A strong risk factor associated with coinfection of HPV and HSV-1 or HSV-2 was woman's age of sexual debut.

The outcome of this work stresses the urgent need to develop public health education programs directed on transmission of HSV and HPV viruses, and their associated risk factors, as well as increased risk on cervical cancer development at least before the onset of amorous relations in girls. It may also be necessary to conduct routine screening of women of reproductive age for herpes infection as a part of health promotion at the hospital setting, because identifying those women at risk would impact on reducing the incidence of herpes infections in the general population. Furthermore, improved and sensitive diagnostic tests for HSV detection should be made affordable in poor settings in the absence of vaccines. This may go a long way to reduce potential morbidity and mortality.

\section{Competing Interests}

The authors declare that they have no competing interests.

\section{Funding}

The research was funded by the authors.

\section{Acknowledgements}

We wish to acknowledge all the study participants.

\section{References}

[1] Looker K. J., Magaret A. S., May M. T., Turner K. M. E., Vickerman P., Gottlied S. L., Newman L. M.. (2015). Global and regional estimates of prevalent and incident herpes simplex virus type 1 infection on 2012. PLoS One, 10:e140765.

[2] Looker K. J., Magaret A. S., Turner K. M., Vickerman P., Gottlieb S. L., Newman L. M. (2015). Global estimates of prevalent and incident herpes simplex virus type 2 infections in 2012. PLoS One, 10:e114989.

[3] Debrah O., Agyemang-Yeboah F., Asmah R. H., TimmyDonkoh, E. Seini M. M., Fondjo L. A., Sight N., Owusu-Dabo E. (2018). Sero-prevalence of herpes simplex virus type 1 and type 2 among women attending routine Cervicare clinics in Ghana. BMC Infect Dis, 18:378. doi:10.1186/s12879-0183288-1.

[4] Lowhagen G. B., Tunback P., Bergstrom T. (2002). Proportion of herpes simplex virus (HSV) type 1 and type 2 among genital and extragenital HSV isolates. Anta Derm Venereol, 82:118-120.

[5] Garceau R., Leblanc D., Thibault L., Girouard G., Mallet M. (2012). Herpes simplex virus type 1 is the leading cause of genital herpes in New Brunswick. Can J Infect Dis Med Microbiol, 23: 15-18.

[6] Gupta R., Warren T. and Wald A. (2007). Genital Herpes. Lancet, 370: 2127-2137.

[7] Anzivino E., Fioriti D., Mischitelli M., Bellizzi A., Barucca V., Chiarini F., Pietropaolo V. (2009). Herpes simplex virus infection in pregnancy and in neonate: status of art of epidemiology, diagnosis, therapy and prevention. Virol J, 6:40. Doi: 10.1186/1743-422X-6-40.

[8] Ohana B., Lipson M., Vered N., Srugo I., Ahdut M., Morag A. (2000). Novel approach for specific detection of herpes simplex virus type 1 and type 2 antibodies and immunoglobulin $\mathrm{G}$ and $\mathrm{M}$ antibodies. Clin Diagn Lab Immunol, 7:904-908. 
[9] del Mar Pujades Rodriguez M., Obasi A., Mosha F., Todd J., Brown D., Changalucha J., Mabey D., Ross D., Grosskurth H., Hayes R. (2002). Herpes simplex virus type 2 infection increases HIV incidence: a prospective study in rural Tanzania. AIDS, 16(3):451-62.

[10] Wald A. andLink K. (2002). Risk of human immunodeficiency virus infection in herpes simplex virus type 2-seropositive persons: a meta-analysis. J Infect Dis, 185(1):45-52.

[11] Cowan F. M., Humphrey J. H., Ntozini R., Mutasa K., Morrow R., Iliff P. (2008). Maternal herpes simplex virus type 2 infection, syphilis and risk of intra-partum transmission of HIV-1: results of a case-control study. AIDS, 22:193-201.

[12] Singh A. E., Romanowski B., Gourishankar S., Myziuk L., Fenton J., Preiksaitis J. K. (2005). Herpes siplex virus seroprevalence and risk factors in 2 Canadian sexually transmitted disease clinics. Sex Transm Dis, 32:95-100.

[13] Szostek S., Zawilinska B., Kopec J., Kosz-Vnenchak M. (2009). Herpesviruses as possible cofactors in HIV-16-related oncogenesis. Acta Biochim Pol, 56:337-342.

[14] IARC (1995). Monographs on the evaluation of carcinogenic riscks to humans. Human papillomaviruses. IARC Monographs 64.

[15] Coutlee F., Gravitt P., Kornegay J., Hankins C., Richardson H., Lapointe N., Voyer H. and Franco E. (2002). Use of PGMY primers in L1 consensus PCR improves detection of human papillomavirus DNA in genital samples. J Clin Microbiol, 40: 902-907.

[16] Gellin J., Brown S., Marshall Graves J. A., Rothschild M., Schook L., Womack J., and Yerle M. (2002). Comparative gene mapping workshop: progress in agriculturally important animals. Mamm Genome, 11:140-144.

[17] WHO/ICO. (2010). Human Papillomavirus and related cancers in the world. In WHO informational Center on HPV and Cervical Cancer (HPV Informational Centre). WHO/ICO.

[18] Schelhass M., Shah M., Holzer M., Blattmann P., Kuhling L., Day P. M, Schiller J. T., Helenius A. (2012). Entry of human papillomavirus type 16 by actin-dependent, clathrin- and lipid raft-independent endocytosis. PLos Pathogenesis, 8:e1002657.

[19] Hara Y., Kimoto T., Okuno Y., and Minekawa Y. (1997). Effect of herpes simplex virus on the DNA of human papillomavirus 18. J Med Virol, 53: 4-12.

[20] Kalu E. I., Ojide C. K., Fowotade A., Nwadike V. U. (2014).
Sexual behavioral correlates with HSV-2 seroprevalence among pregnant women in Nigeria. J. Infect. Dev. Ctries, 8(8):1006-1012.

[21] Smith J. S., Herrero R., Bosetti C., Munoz N., Bosch F. X., Eluf-Neto J., Castellsague X., Meijer C. J., Van den Brule A. J., Franceschi S., Ashley R. (2002). Herpes simplex virus-2 as a human papillomavirus cofactor in the etiology of invasive cervical cancer. J Natl Cancer Inst, 94: 1604-1613.

[22] Brady R. C. and Bernstein D. I. (2004). Treatment of herpes simplex virus infections. Antiviral Res, 61:73-81.

[23] York I. A., Roop C., Andrews D. W., Riddell S. R., Graham F. L., Johnson D. C. (1994). A cytosolic herpes simplex virus protein inhibits antigen presentation to $\mathrm{CD} 8+\mathrm{T}$ lymphocytes. Cell, 77(4): 525-535.

[24] Wiredu E. K. and Armah H. B. (2006). Cancer mortality patterns in Ghana: a ten year review of autopsies and hospital mortality. BMC Public Health, 6:156-159.

[25] ICO/IARC. (2016). Human papillomavirus and related disease report. Ghana. In ICO/IARC Informational Center on HPV and Cancer. www.hpvcentre.net/statistics/reports/GHA.

[26] Nyiro J. U., Snders E. J., Ngetsa C., Wale S., Awuondo K., Bukusi E., Price M. A., Amornkul P. N., James Nokes D. (2011). Seroprevalence, predictors and estimated incidence of maternal and neonatal Herpes simplex virus type 2 infection in semi-urban women in Kilifl, Kenya. BMC Infect Dis, 11:155.

[27] Santos F. C., de Oliveira S. A., Setubal S., Camacho L. A. B., Faillace T., Leite J. P. G. Velarde L. G. (2006). Seroepidemiological study of herpes simplex virus type 2 in patients with the acquired immunodeficiency syndrome in the city of Niteroi, Rio de Janeiro, Brazil. Mem Inst Oswaldo Cruz, 101(3):315-319.

[28] Agboeze J., Umeora O., Ozumba B., Onoh R., Ezeonu P., Edegbe F. (2005). Prevalence and pattern of abnormal cervical smear among women infected with HIV in Abakaliki, Nigeria. African Journal of Med and Health Scxiences, 1492):92-95.

[29] Coker A. L., Richter D. L., Valois R. F., McKeown R. E., Garrison C., Vincent M. L. (1994). Correlates and consequences of early initiation of sexual intercourse. J. Sch. Health, 64:372-377.

[30] Andersson-Ellstrom A., Forssman L., Milsom, I. (1996). Age of sexual debut related to life-style and reproductive health factors in a group of Swedish teenage girls. Acta Obstet. Gynecol. Scand, 75:484-489. 